\title{
UJI AKTIVITAS ANTIBAKTERI EKSTRAK ETANOL BIJI KAMANDRAH (Croton tiglium L.) TERHADAP PERTUMBUHAN Salmonella typhi DENGAN METODE DIFUSI CAKRAM (KIRBY-BAUER)
}

\author{
Revina Destiana Samputri ${ }^{1}$,Angeline Novia Toemon ${ }^{2}$ dan Ratna Widayati ${ }^{3}$ \\ ${ }^{\text {I} P r o g r a m ~ S t u d i ~ P e n d i d i k a n ~ D o k t e r, ~ F a k u l t a s ~ K e d o k t e r a n, ~ U n i v e r s i t a s ~ P a l a n g k a ~ R a y a, ~ P a l a n g k a ~ R a y a, ~}$ \\ Indonesia \\ 2.3 Staff Pengajar Fakultas Kedokteran Universitas Palangka Raya, Palangka Raya, Indonesia \\ E-mail: destianasamputri@gmail.com
}

\begin{abstract}
Salmonella typhi is a gram-negative rod which has no spores that can move with peritrich flagellum, that is intracellular and anerobic. The most common disease due to the bacterium Salmonella typhi is typhoid fever. Kamandrah (Croton tiglium L.) is a plant derived from Euphorbiaceae tribe that can be used as an antibacterial. To determine whether ethanol extract of Kamandrah seeds (Croton tiglium L.) can inhibit the growth of Salmonella typhi bacteria by using Kirby-Bauer disk diffusion method. this study is a true experiment design with research design of Post Test only control group design. Research subjects used the Salmonella typhi bacterial culture. This study used 7 treatment groups, with concentrations of $20 \%, 40 \%, 60 \%, 80 \%, 100 \%$ and positive control of Chloramphenicol $30 \mu \mathrm{g}$ and negative control of dimethyl sulfoxide (DMSO) as a negative control. The method that used for testing antibacterial activity is the Kirby-Bauer disk diffusion method. Data analysis using the KruskalWallis test on SPSS application. the results that Kamandrah seeds (Croton tiglium L.) could not inhibit the growth of Salmonella typhi with an average inhibition zone concentration of $20 \%(0.00 \mathrm{~mm}), 40 \%(0.00 \mathrm{~mm}), 60 \%(0.00 \mathrm{~mm}$ ), $80 \%(0.00 \mathrm{~mm})$, and $100 \%(0.00 \mathrm{~mm})$. Positive control $(28.2 \mathrm{~mm})$ and negative control $(0.00 \mathrm{~mm})$. Kruskal Wallis Test $(\mathrm{P}=0,000)$. Ethanol extract of Kamandrah seeds (Croton tiglium L.) can not inhibit the growth of Salmonella typhi and there is no more the most effective concentration of ethanol extract of Kamandrah seeds (Croton tiglium L.) which can inhibit the growth of Salmonella typhi bacteria.
\end{abstract}

Keywords: Salmonella typhi, Kamandrah seeds, Antibacterial, Kirby-Bauer discs.

\section{ABSTRAK}

Salmonella typhi merupakan batang gram negatif, yang tidak memiliki spora, dapat bergerak dengan flagel peritrich, bersifat intraseluler dan anerob. Penyakit yang paling umum terjadi karena bakteri Salmonella typhi adalah demam tifoid. Kamandrah (Croton tiglium L.) merupakan suatu tanaman yang berasal dari suku Euphorbiaceae dapat digunakan sebagai antibakteri. Untuk mengetahui apakah ekstrak etanol biji Kamandrah (Croton tiglium L.) dapat menghambat pertumbuhan bakteri Salmonella typhi dengan metode difusi cakram Kirby-bauer. penelitian ini merupakan true experiment design dengan rancangan penelitian Post test only control group design. Subjek penelitian menggunakan biakan bakteri Salmonella typhi. Penelitian ini menggunakan 7 kelompok perlakuan, yaitu

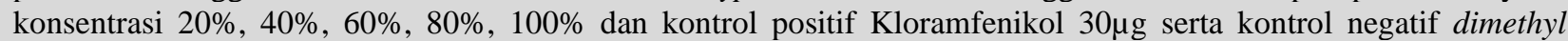
sulfoxide (DMSO) sebagai kontrol negatif. Metode yang digunakan untuk pengujian aktivitas antibakteri menggunakan metode difusi cakram Kirby-bauer. Analisis data menggunakan uji Kruskal-Wallis dalam aplikasi SPSS. hasil bahwa biji Kamandrah (Croton tiglium L.) tidak dapat menghambat pertumbuhan Salmonella typhi dengan rata-rata zona hambat konsentrasi $20 \%(0,00 \mathrm{~mm}), 40 \%(0,00 \mathrm{~mm}), 60 \%(0,00 \mathrm{~mm}), 80 \%(0,00 \mathrm{~mm})$, dan $100 \%(0,00 \mathrm{~mm})$. kontrol positif $(28,2 \mathrm{~mm})$ serta kontrol negatif $(0,00 \mathrm{~mm})$. Uji Kruskal - Wallis $(P=0,000)$. Ekstrak etanol biji Kamandrah (Croton tiglium L.) tidak dapat menghambat pertumbuhan Salmonella typhi dan tidak terdapat konsentrasi paling efektif ekstrak etanol biji Kamandrah (Croton tiglium L.) yang dapat menghambat pertumbuhan bakteri Salmonella typhi.

Kata Kunci: Salmonella typhi, biji Kamandrah, Antibakteri, Cakram Kirby-Bauer. 


\section{PENDAHULUAN}

Salmonella typhi merupakan batang gram negatif, yang tidak memiliki spora, dapat bergerak dengan flagel peritrich, bersifat intraseluler dan anerob. ${ }^{1}$ Salmonella typhi dapat ditularkan melalui konsumsi makanan atau air yang terkontaminasi.

Menurut World Health Organization (WHO) tahun 2013 memperkirakan angka insidensi di seluruh dunia sekitar 17 juta jiwa per tahun, angka kematian demam tifoid mencapai 600.000 dan $70 \%$ terjadi di Asia. Menurut World Health Organization (WHO) angka penderita demam tifoid di Indonesia mencapai $81 \%$ per $100.000 .^{3}$ Menurut data Dinas Kesehatan Provinsi Kalimantan Tengah tahun 2018 angka kejadian demam tifoid bulan Januari sampai Desember terdapat 896 penderita demam tifoid klinis dan sebanyak 1.644 penderita dengan tes widal positif. ${ }^{4}$ Menurut pelaporan data rekam medis rawat inap Rumah Sakit Umum Daerah dr. Doris Sylvanus Kota Palangka Raya tahun 2018 terdapat 11 penderita rawat inap dan 22 penderita rawat jalan demam tifoid. ${ }^{5}$ Hasil tersebut membuktikan bahwa kecenderungan penyakit yang disebabkan bakteri masih dialami oleh penduduk Indonesia. Salah satunya adalah karena infeksi Salmonella typhi, yaitu penyebab penyakit demam tifoid.

Pengobatan demam tifoid sampai saat ini masih menggunakan antibiotik. Salah-satunya adalah menggunakan kloramfenikol sebagai obat lini pertama pengobatan demam tifoid. Kloramfenikol merupakan antibiotik berspektrum luas yang sensitif terhadap bakteri gram negatif.

Berdasarkan efektivitasnya terhadap Salmonella typhi disamping obat tersebut relatif murah, namun beberapa penelitian menunjukkan bahwa angka relaps pada pengobatan demam tifoid dengan menggunakan kloramfenikol tinggi, sehingga perlu diupayakan suatu pengobatan alternatif antibakteri. ${ }^{6}$

Penggunaan obat herbal semakin berkembang luas dengan penelitian-penelitian terbaru dimana obat tradisional digunakan untuk mengobati penyakit dalam beberapa generasi. ${ }^{7}$ Salah satu tanaman lokal di Kalimantan Tengah yaitu Kamandrah (Croton tiglium L.) merupakan suatu tanaman yang berasal dari suku Euphorbiaceae.

Tumbuhan ini memiliki bermacam nama sesuai daerah masing-masing seperti Simalakian, Kamandrah, Ceraken, Roengkok, Semoeki, dan Kowe. ${ }^{8}$ Diketahui tumbuhan dari 
genus Croton memiliki bioaktivitas antihipertensi, antiinflamasi, antimalaria, antimikroba, dan antivirus. ${ }^{9}$

Berdasarkan studi pendahuluan yang dilakukan oleh peneliti di Desa Timpah Kabupaten Kapuas tengah dalam bentuk kuisioner yang disebarkan ke 50 orang responden, pemanfaatan tanaman Kamandrah sebagai pengobatan tradisional mencapai $100 \%$ dan sebanyak 50\% menggunakan Kamandrah sebagai pengobatan untuk sembelit. Sisanya menggunakan Kamandrah sebagai obat tradisional berbagai penyakit seperti penyakit tifus, demam, kulit dan nyeri punggung.

Berdasarkan hasil skrining fitokimia yang telah dilakukan penelitian sebelumnya, menunjukkan pada biji Kamandrah terdapat saponin, steroid, flavonoid, alkaloid, dan tanin. ${ }^{8}$ Adanya kandungan senyawa tersebut diduga dapat bekerja sebagai antimikroba atau antibakteri membuat biji Kamandrah memiliki aktivitas antibakteri bagi bakteri Salmonella typhi.

Berdasarkan uraian di atas, maka perlu dilakukan uji aktivitas antibakteri biji Kamandrah (Croton tiglium L.) terhadap Salmonella typhi dalam rangka membuktikan adanya kandungan antibakteri dalam biji Kamandrah. Penelitian ini dilakukan secara in vitro dengan metode difusi cakram KirbyBauer.

\section{METODE PENELITIAN}

\section{Jenis dan Rancangan Penelitian}

Jenis penelitian ini adalah penelitian true experiment design, yaitu jenis penelitian dimana peneliti akan mengontrol semua variabel luar yang mempengaruhi jalannya eksperimen. Rancangan yang digunakan dalam penelitian ini yaitu eksperimen dengan metode post test-only control group design.

\section{Sampel dan Teknik Pengambilan Sampel}

Sampel pada penelitian ini adalah koloni Salmonella typhi. Pengambilan sampel dilakukan dengan teknik randomisasi, yaitu koloni Salmonella typhi yang tumbuh pada media secara acak. Sampel diambil menggunakan jarum ose. ${ }^{33}$

Perhitungan besar sampel untuk setiap perlakuan ditentukan dengan menggunakan rumus Federer yaitu: $(\mathrm{t}-1)(\mathrm{n}-1) \geq 15$ dimana, $\mathrm{t}=$ jumlah perlakuan dalam penelitian, $n=$ jumlah pengulangan sampel. Jadi, jumlah perlakuan ada 5 yaitu perlakuan pada konsentrasi $20 \%, 40 \%, 60 \%, 80 \%$, dan $100 \%$ ditambah dengan 2 perlakuan kontrol yaitu 1 perlakuan untuk kontrol positif, 1 perlakuan untuk kontrol negatif, dengan pengulangan sebanyak 4 kali. 


\section{Prosedur}

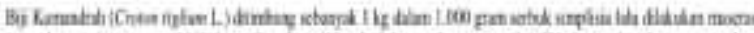

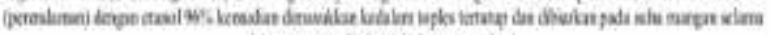

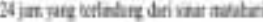

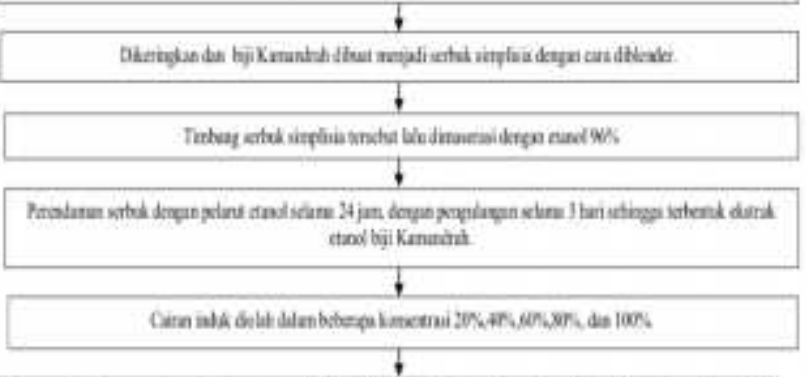

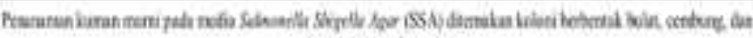
bevira mentas

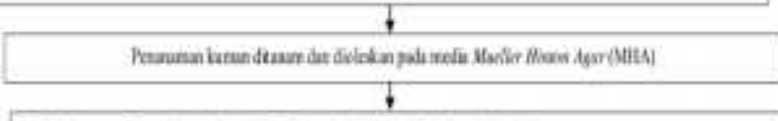

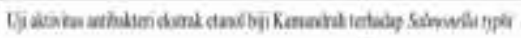

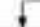

Kantilategati

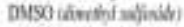

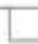

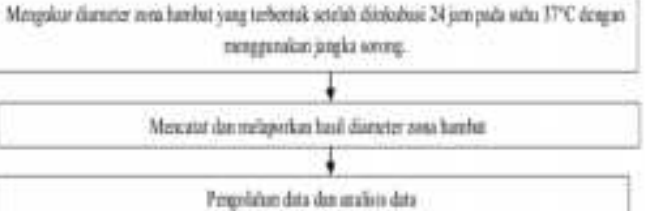

\section{HASIL DAN PEMBAHASAN}

Hasil uji fitokimia dari tumbuhan biji Kamandrah (Croton tiglium L.) yang telah diambil dari daerah Kabupaten Kapuas Tengah, Kecamatan Timpah, Kalimantan Tengah, yang dilakukan di Laboratorium Biokimia dan Biomolekuler Fakultas Kedokteran Universitas

Lambung Mangkurat Banjar Baru dengan hasil skrining fitokimia secara kuantitatif sebagai berikut: 
Tabel 1. Hasil Uji Fitokimia

\begin{tabular}{llll}
\hline Senyawa fitokimia & Metode & Kadar $(\mathbf{X} \pm$ Std $)$ & Keterangan \\
\hline Saponin $(\%)$ & Gravimetri & $25,479 \pm 1,867$ & Triplo \\
Alkaloid $(\%)$ & Gravimetri & $6,136 \pm 3,935$ & Triplo \\
Flavonoid $(\mathrm{mg} / \mathrm{ml} \mathrm{QE)}$ & Kolorimetri & $19.500 \pm 0,661$ & Triplo \\
Steroid $(\mathrm{mg} / \mathrm{ml})$ & Kolorimetri & $24.909 \pm 4,613$ & Triplo \\
Tanin $(\mathrm{mg} / \mathrm{ml} \mathrm{QE)}$ & Kolorimetri & $0,426 \pm 0,014$ & Triplo \\
\hline
\end{tabular}

Biji kamandrah (Croton tiglium L.) yang diteliti adalah bagian buah yang berwarna hijau segar yang didalamnya terdapat biji. Biji yang sudah dikeringkan dan dibuat menjadi simplisia diekstraksi dengan metode maserasi menggunakan etanol $96 \%$ selama 24 jam kemudian dipisahkan filtrat dengan ampas menggunakan kertas saring, maserasi diulangi sebanyak 3 kali dan digabungkan semua hasil filtrat setelah itu dilakukan penguapan dengan Rotatory evaporator dan waterbath untuk memisahkan etanol dengan ekstrak agar memperoleh ekstrak kental yang optimal dengan hasil sebagai berikut:

Tabel 2. Hasil Ekstraksi Tumbuhan Kamandrah (Croton tiglium L.)

\begin{tabular}{cccccc}
\hline $\begin{array}{c}\text { Berat } \\
\text { awal }\end{array}$ & $\begin{array}{c}\text { Berat Biji Setelah } \\
\text { dikeringkan }\end{array}$ & Berat Simplisia & $\begin{array}{c}\text { Hasil } \\
\text { filtrat }\end{array}$ & $\begin{array}{c}\text { Ekstrak } \\
\text { Kental }\end{array}$ & Rendemen \\
\hline $1.000 \mathrm{~g}$ & $500 \mathrm{~g}$ & $400 \mathrm{~g}$ & $2.100 \mathrm{ml}$ & $42,83 \mathrm{~g}$ & $10,70 \%$ \\
\hline
\end{tabular}

Ekstrak kental yang didapatkan dari 1.000 g biji Kamandrah adalah 42,83 g dimana didapatkan rendemen sebesar 10,70\%.

Penelitian ini menguji aktivitas antibakteri ekstrak etanol biji kamandrah (Croton tiglium L.) terhadap pertumbuhan bakteri Salmonella typhi dengan metode difusi cakram (Kirbybauer) pada media Muller Hinton Agar (MHA) dengan berbagai konsentrasi, yaitu pada konsentrasi $20 \%, 40 \%, 60 \%, 80 \%$, dan $100 \%$ serta kontrol positif yaitu kloramfenikol $30 \mu \mathrm{g}$ dan kontrol negatif yaitu $10 \mathrm{ml}$ dimetil sulfoxide (DMSO). Aktivitas antibakteri tersebut dapat dilihat dengan terbentuk zona hambat, yaitu daerah berwarna bening yang 
tidak ditumbuhi bakteri dengan hasil sebagai

berikut:

Tabel 3. Hasil Pengukuran Diameter Zona Hambat yang Terbentuk pada media Mueller Hinton Agar (MHA)

\begin{tabular}{cccccccc}
\hline Diameter & \multicolumn{7}{c}{ Kelompok Perlakuan } \\
\cline { 2 - 7 } $\begin{array}{c}\text { Zona hambat } \\
(\mathrm{mm})\end{array}$ & $20 \%$ & $40 \%$ & $60 \%$ & $80 \%$ & $100 \%$ & $\begin{array}{c}\text { Kontrol positif } \\
(+)\end{array}$ & $\begin{array}{c}\text { Kontrol negatif } \\
(-)\end{array}$ \\
\hline I & 0 & 0 & 0 & 0 & 0 & 28,3 & 0 \\
II & 0 & 0 & 0 & 0 & 0 & 28,4 & 0 \\
III & 0 & 0 & 0 & 0 & 0 & 28,0 & 0 \\
IV & 0 & 0 & 0 & 0 & 0 & 28,1 & 0 \\
Rata-rata & 0 & 0 & 0 & 0 & 0 & 28,2 & 0 \\
\hline
\end{tabular}

Diatas diketahui bahwa konsentrasi 20\%, 40\%, $60 \%$, $80 \%$, dan $100 \%$ tidak terbentuk zona hambat pada media Muller Hinton Agar yang telah ditumbuhkan bakteri Salmonella typhi. Kontrol positif memiliki nilai rata-rata zona hambat sebesar 28,2 $\mathrm{mm}$ dan kontrol negatif tidak terbentuk zona hambat.

Analisis data pada penelitian ini menggunakan SPSS versi 23. Analisis pendahuluan untuk uji normalitas dilakukan pada variabel diameter zona hambat. Hasil dari masing-masing diameter zona hambat akan dilanjutkan dengan menganalisis distribusi data tersebut untuk mengetahui apakah data normal atau tidak sebelum melakukan analisis One Way Anova. Pada uji normalitas didapatkan distribusi data tidak normal dan tidak homogen sehingga digunakan analisis non parametrik Kruskal Wallis lalu dilanjutkan dengan uji post hoc. Hasil uji normalitas menggunakan Shapiro wilk karena data kurang dari 50. Berdasarkan uji normalitas menggunakan Shapiro wilk didapatkan nilai signifikan yaitu 0,000 yang berarti nilai $p<0,05$ artinya data yang didapatkan tidak terdistribusi normal. Selanjutnya dilakukan uji homogenitas untuk mengetahui data homogen atau tidak. Pada uji homogenitas Levene test didapatkan nilai signifikan yaitu 0,000 yang berarti nilai $p<$ 0,05 artinya data yang didapatkan tidak homogen. Data yang didapat dari uji normalitas dan uji homogenitas menunjukan bahwa data tidak terdistribusi normal dan data tidak homogen sehingga syarat One Way Anova tidak terpenuhi, yaitu data terdistribusi normal dan 
varian data homogen. Sehingga digunakan uji non parametrik Kruskal -Wallis. Berdasarkan analisis data non parametrik Kruskal -Wallis didapatkan nilai $p=0,000$ karena nilai $p<0,05$ maka dapat diambil kesimpulan bahwa terdapat perbedaan bermakna antara ketujuh kelompok perlakuan pada bakteri uji. Selanjutnya, untuk mengetahui kelompok mana yang mempunyai perbedaan maka harus dilakukan analisis Post Hoc. Alat untuk melakukan analisis Post Hoc untuk uji Kruskal-Wallis adalah dengan uji Mann Whitney seperti berikut:

Tabel 4. Hasil Analisis Pos Hoc (Mann Whitney) Perbedaan Pengaruh Ekstrak etanol biji Kamandrah

\begin{tabular}{cccccccc}
\hline Perlakuan & $20 \%$ & $40 \%$ & $60 \%$ & $80 \%$ & $100 \%$ & Kontrol + & Kontrol - \\
\hline $20 \%$ & & 1,000 & 1,000 & 1,000 & 1,000 & 0,014 & 1,000 \\
$40 \%$ & 1,000 & & 1,000 & 1,000 & 1,000 & 0,014 & 1,000 \\
$60 \%$ & 1,000 & 1,000 & & 1,000 & 1,000 & 0,014 & 1,000 \\
$80 \%$ & 1,000 & 1,000 & 1,000 & & 1,000 & 0,014 & 1,000 \\
$100 \%$ & 1,000 & 1,000 & 1,000 & 1,000 & & 0,014 & 1,000 \\
Kontrol + & 0,014 & 0,014 & 0,014 & 0,014 & 0,014 & & 1,000 \\
Kontrol - & 1,000 & 1,000 & 1,000 & 1,000 & 1,000 & 0,014 & \\
\hline
\end{tabular}


Berdasarkan uji Mann Whitney didapatkan perlakuan dengan konsentrasi $20 \%$ dengan kontrol positif, 40\% dengan kontrol positif, $60 \%$ dengan kontrol positif, $80 \%$ dengan kontrol positif, $100 \%$ dengan kontrol positif, kontrol negatif dengan kontrol positif didapatkan nilai $p=0,014(p<0,05)$ memiliki perbedaan bermakna sehingga menunjukan ada perbedaan daya hambat yang bermakna secara statistik terhadap bakteri uji sedangkan jika masing-masing konsentrasi ekstrak etanol biji Kamandrah dibandingkan dengan berbagai konsentrasi ekstrak didapatkan nilai $p=1,000(p>0,05)$ memiliki tidak terdapat perbedaan bermakna sehingga menunjukan tidak ada perbedaan daya hambat yang bermakna pada konsentrasi $20 \%, 40 \%, 60 \%, 80 \%$, dan $100 \%$.

Proses awal pembuatan ekstrak etanol biji Kamandrah (Croton tiglium L.) adalah tahapan pembuatan simplisia kering (penyerbukan). Simplisia dibuat dengan peralatan tertentu sampai derajat kehalusan tertentu dan homogen. Proses ini dapat mempengaruhi mutu ekstrak dengan dasar beberapa hal salah satunya, yaitu makin halus serbuk simplisia, proses ekstraksi makin efektif. Pada penelitian ini digunakan sampel berupa biji Kamandrah (Croton tiglium L.) yang diblender sampai halus hingga menjadi serbuk simplisia dengan tujuan untuk meningkatkan luas permukaan sampel sehingga pelarut lebih mudah masuk ke dalam sel dan menarik komponen yang aktif untuk keluar dari sel tumbuhan. ${ }^{36}$

$$
\text { Maserasi merupakan proses }
$$
pengekstrakan simplisia menggunakan pelarut yang dipilih untuk penelitian ini. Maserasi dilakukan dengan cara merendam serbuk simplisia biji Kamandrah (Croton tiglium L.) ke dalam pelarut etanol $96 \%$. Pelarut akan menembus dinding sel dan masuk ke dalam rongga sel yang mengandung zat aktif, zat aktif akan larut dan karena adanya perbedaan konsentrasi antara larutan zat aktif di dalam sel dengan yang di luar sel, maka larutan yang terpekat akan didesak keluar. Peristiwa tersebut berulang sehingga terjadi keseimbangan konsentrasi antara larutan di luar sel dan di dalam sel. ${ }^{36}$

Maserasi sampel dilakukan dengan menggunakan pelarut etanol karena sifatnya yang mampu melarutkan hampir semua zat, baik yang bersifat polar, semi polar dan non polar serta kemampuannya untuk mengendapkan protein dan menghambat kerja enzim sehingga dapat terhindar dari proses hidrolisis dan oksidasi. Etanol sangat efisien untuk ekstraksi dari berbagai konstituen tanaman. $^{37}$

Hasil filtrat pertama, kedua dan yang ketiga dari proses pengekstrakan etanol biji Kamandrah (Croton tiglium L.) dipisahkan dengan pelarutnya menggunakan Rotary Evaporator yang pada penelitian ini menggunakan pelarut etanol yang digunakan 
saat merendam simplisia biji Kamandrah (Croton tiglium L.) dan kemudian menggunakan Waterbath dengan tujuan melakukan pemekatan untuk membuat ekstrak etanol biji Kamandrah (Croton tiglium L.) menjadi kental. Penguapan dapat terjadi karena adanya pemanasan. Prinsip kerja Rotary Evaporator adalah menguapkan larutan etanol yang terdapat dalam ekstrak etanol biji Kamandrah (Croton tiglium L.) dengan suhu yang tidak terlalu tinggi yaitu $70^{\circ} \mathrm{C}$ kemudian suhu pada saat pemekatan menggunakan Waterbath menggunakan suhu $70^{\circ} \mathrm{C}$ dan pada kedua proses tersebut menghasilkan ekstrak etanol biji Kamandrah (Croton tiglium L.) kental sebanyak 42,83 g. Pada penelitian ini ekstrak biji Kamandrah dipekatkan menggunakan Rotary Evaporator dan Waterbath karena jika ekstrak dipekatkan sepenuhnya menggunakan Rotary Evaporator, ekstrak akan sulit dikeluarkan dari Rotary Evaporator karena Rotary Evaporator memiliki mulut tabung yang kecil dan keterbatasan batang pengaduk untuk mengeluarkannya dari Rotary Evaporator, sehingga dilanjutkan dengan menggunakan waterbath ketika ekstrak terlihat sedikit mengental.

Berdasarkan penelitian sebelumnya yang pernah dilakukan oleh Saputera bahwa ekstrak etanol biji Kamandrah dari kandungan minyak mengandung senyawa metabolik sekunder seperti alkaloid, flavonoid, dan saponin. ${ }^{8}$ Hasil identifikasi metabolit sekunder didapatkan bahwa biji Kamandrah (Croton tiglium L.) yang diambil daerah Kabupaten Kapuas Tengah, Kecamatan Timpah, Kalimantan Tengah yang memiliki kandungan senyawa metabolik sekunder yaitu saponin, steroid, flavonoid, alkaloid, dan tanin. Masing-masing senyawa metabolik sekunder memiliki cara kerja yang berbedabeda.

Mekanisme kerja saponin sebagai antibakteri adalah menurunkan tegangan permukaan sehingga mengakibatkan naiknya permeabilitas atau kebocoran sel dan mengakibatkan senyawa intraseluler akan keluar menyebabkan stabilitas membran sel bakteri terganggu sehingga dapat mengakibatkan sel bakterilisis. ${ }^{38}$ Mekanisme kerja steroid sebagai antibakteri adalah dengan merusak membran plasma sel mikroba, sehingga menyebabkan bocornya sitoplasma keluar sel yang selanjutnya menyebabkan kematian sel disebabkan karena molekul steroid memiliki gugus non polar (hidrofobik) dan polar (hidrofilik) sehingga memiliki efek surfaktan yang dapat melarutkan komponen fosfolipid membran plasma. ${ }^{28}$

Mekanisme kerja flavonoid sebagai antibakteri adalah membentuk senyawa kompleks dengan protein ekstraseluler dan terlarut sehingga dapat merusak membran sel 
bakteri dan diiikuti dengan keluarnya senyawa intraseluler. ${ }^{22,23,24}$

Mekanisme kerja alkaloid sebagai antibakteri adalah menghambat sintesis protein dinding sel yang akan menyebabkan lisis pada sel sehingga sel akan mati. ${ }^{25,26}$ Mekanisme kerja tanin sebagai antibakteri adalah menginaktifkan adhesin sel mikroba juga menginaktifkan enzim dan mengganggu transport protein pada lapisan dalam sel. Tanin juga mempunyai target pada polipeptida dinding sel sehingga pembentukan dinding sel menjadi kurang sempurna. Hal ini menyebabkan sel bakteri menjadi lisis karena tekanan osmotik maupun fisik sehingga sel bakteri akan mati. ${ }^{23}$

Salmonella typhi adalah bakteri gram negatif yang disusun oleh membran luar dan membran dalam. Lapisan membran luar bakteri gram negatif mengandung fosfolipid, lipopolisakarida, dan lipoprotein. Lapisan ini impermeabel terhadap molekul berukuran besar. Sementara lapisan dalam sangat impermeabel terhadap molekul berukuran kecil. Sehingga suatu senyawa antibakteri sukar untuk menembus struktur bakteri Gram negatif. Permeabilitas membran luar dinding sel bakteri gram negatif ditentukan oleh adanya protein tertentu disebut porin. Porin mempengaruhi difusi pasif komponen hidrofilik dengan berat molekul rendah seperti gula, asam amino, dan beberapa jenis ion, namun impermeable terhadap molekul berukuran besar. Molekul antibakteri berukuran besar relatif lambat saat menembus membran luar yang menyebabkan bakteri gram negatif lebih resisten terhadap senyawa antibakteri. $^{39}$

Pada penelitian ini menggunakan konsentrasi ekstrak etanol biji Kamandrah (Croton tiglium L.) yaitu 20\%, 40\%, 60\%, $80 \%$, dan $100 \%$. Penggunaan kontrol negatif DMSO dikarenakan tidak mempunyai pengaruh terhadap pertumbuhan bakteri uji. ${ }^{39}$ Hasil yang didapatkan dari uji aktivitas antibakteri biji Kamandrah (Croton tiglium L.) didapatkan bahwa masing-masing konsentrasi $20 \%, 40 \%, 60 \%, 80 \%$, dan $100 \%$ serta kontrol negatif tidak membentuk zona hambat. Sedangkan Kontrol positif, yaitu antibiotik kloramfenikol $30 \mu \mathrm{g}$ yang telah tersedia dalam bentuk disc menunjukan ratarata diameter zona hambat sebesar $28,2 \mathrm{~mm}$ yang berarti antibiotik ini sensitif menghambat pertumbuhan Salmonella typhi berdasarkan tabel standar CLSI, zona hambat kloramfenikol dikatakan sensitif menunjukkan diameter zona hambat $\geq 18 \mathrm{~mm}$ menunjukkan hasil Sensitif, zona hambat terhadap antibiotik kloramfenikol dengan diameter 13-17 $\mathrm{mm}$ menunjukkan hasil intermediate dan zona hambat terhadap antibiotik kloramfenikol dengan diameter $\leq$ $12 \mathrm{~mm}$ menunjukkan hasil resistant. ${ }^{16}$

Selain itu, keterbatasan dalam penelitian ini senyawa metabolik sekunder 
belum spesifik yang didapatkan dari ekstrak etanol biji Kamandrah untuk menghambat pertumbuhan Salmonella typhi sehingga senyawa tanin, alkaloid, flavonoid, saponin, dan steroid tidak dapat menembus dinding Salmonella typhi yang tersusun lipoprotein, fosfolipid, dan lipopolisakarida. ${ }^{39}$ Menurut Lim et al senyawa turunan tanin seperti tanin hidrolisis ditemukan memiliki aktivitas antibakteri yang memiliki mekanisme merusak dinding sel bakteri.${ }^{40}$ Menurut More et al fraksi alkaloid terisolasi tidak dapat melawan bakteri gram negatif. Hal ini disebabkan karena membran luar bakteri negatif memiliki barrier penetrasi berbagai molekul antibakteri dan ruang periplasma mengandung enzim yang mampu mendegradasi molekul eksogen. ${ }^{41}$ Menurut Bhuiyan et al, senyawa flavonoid memiliki golongan turunan senyawa yang memiliki aktivitas antibakteri seperti golongan isoflavon karena adanya gugus fenol. ${ }^{42}$ Menurut Hassan, saponin diklasifikasikan menjadi saponin steroid dan saponin triterpenoid. Saponin steroid tersusun atas inti steroid dengan memiliki molekul karbohidrat. Saponin steroid dihirolisis menghasilkan suatu aglikon dikenal sebagai saraponin. Saponin triterpenoid tersusun atas inti triterpenoid dengan molekul karbohidrat yang dihidrolisis menghasilkan suatu aglikon yang disebut sebagai sapogenin. Tipe saponin ini adalah turunan $\beta$-amyirine yang dapat menurunkan tegangan permukaan dinding sel bakteri. ${ }^{43}$ Menurut Hyldgaard, turunan senyawa steroid (terpenoid) adalah golongan monoterpenoid seperti carvacrol dan thymol yang dapat melisiskan membran sel bakteri. ${ }^{44}$ Menurut Cardoso et al tumbuhan Croton dari genus Euphorbiaceae dari hasil uji fitokimia terdapat casbane diterpene 1,4 - dihydroxy2E,6E,12E-trien-5-one-casbane dari senyawa metabolit sekunder diterpenoid terhadap bakteri mulut. $^{45}$

Berdasarkan penelitian yang pernah dilakukan oleh Kusumawati Eko et al bahwa ekstrak etanol daun Kecombrang (Etlingera elatior) mempunyai aktivitas antibakteri terhadap Salmonella typhi yang mengandung senyawa yang berperan sebagai antibakteri seperti saponin, flavonoid, dan tanin. Jenis tanin yang terkandung di dalam ekstrak etanol daun Kecombrang adalah tanin terkondensasi seperti cathecin dan gallocathecin. ${ }^{46}$

Pada penelitian ini, ekstrak etanol biji Kamandrah tidak mempunyai aktivitas antibakteri terhadap Salmonella typhi. Pada antibakteri Kloramfenikol yang digunakan sebagai kontrol positif pada penelitian ini, yang bersifat bakterisid. Antibiotik Kloramfenikol memiliki mekanisme menghambat sintesis protein bakteri pada ribosom subunit 50S dan menghambat enzim peptidil transferase sehingga ikatan peptida tidak terbentuk pada proses sintesis protein bakteri. ${ }^{15}$ Mekanisme kerja Kloramfenikol 
mirip dengan cara kerja alkaloid dan tanin sebagai antibakteri. Berdasarkan skrining fitokimia yang telah dilakukan oleh peneliti menunjukan bahwa kandungan senyawa metabolit sekunder alkaloid 6,136 \% dan tanin $0,426 \mathrm{mg} / \mathrm{ml} \mathrm{QE} \mathrm{dengan} \mathrm{kadar} \mathrm{rendah}$ sehingga diduga senyawa tersebut tidak adekuat untuk menghambat pertumbuhan Salmonella typhi.

\section{KESIMPULAN DAN SARAN}

Berdasarkan data dan pembahasan pada penelitian ini dapat disimpulkan ekstrak etanol biji Kamandrah (Croton tiglium L.) tidak dapat menghambat pertumbuhan bakteri Salmonella typhi dan tidak terdapat konsentrasi paling efektif ekstrak etanol biji Kamandrah (Croton tiglium L.) yang dapat menghambat pertumbuhan bakteri Salmonella typhi dengan metode difusi cakram (KirbyBauer).

Penelitian tentang pemberian ekstrak etanol biji Kamandrah (Croton tiglium L.) terhadap pertumbuhan bakteri Salmonella typhi dengan metode difusi cakram KirbyBauer masih terdapat kekurangan, sehingga disarankan untuk penelitian selanjutnya dapat meneliti uji aktivitas antibakteri bakteri gram positif dengan metode dilusi cair dan Isolasi zat aktif pada tumbuhan Kamandrah (Croton tiglium L.) sehingga mengetahui zat spesifik yang bekerja sebagai antibakteri.

\section{DAFTAR PUSTAKA}

1. Brook GF, Carroll KC, Jawetz, Melnick \& Adelberg, et al. Mikrobiologi Kedokteran Jawetz, Melnick \& Adelberg. 25 $5^{\text {th }}$ ed. Jakarta: EGC;2013

2. Cita Yatnita Parama. Bakteri Salmonella typhi dan demam tifoid. Jurnal Kesehatan Masyarakat. Jakarta.2011;6(1):42-6.

3. Depkes RI. Sistematika Pedoman Pengendalian Penyakit Demam Tifoid. Jakarta: Direktorat Jendral Pengendalian Penyakit \& Penyehatan Lingkungan.2013

4. Dinas Kesehatan Provinsi Kalimantan Tengah. Surveilans Terpadu Penyakit Berbasis Puskesmas. Palangka Raya: Dinas Kesehatan Provinsi. 2017

5. Rumah Sakit Umum Daerah dr. Doris Sylvanus. Pelaporan Data Rekam Medis. Palangka Raya. 2017

6. Alam Anggraini. Pola Resistensi Salmonella Enterica Serotipe Typhi, Departemen Ilmu Kesehatan Anak RSHS, Tahun 2006-2010. Bagian Ilmu Kesehatan Anak, Fakultas Kedokteran Universitas Padjajaran. Sari pediatri. Bandung.2011;2(5): 296-301.

7. Hernani. Pengembangan Biofarmaka sebagai Obat Herbal untuk Kesehatan. Buletin Teknologi Pascapanen Pertanian Bogor. 2011;7(1):20-29.

8. Saputera. Katerisasi Biji Kamandrah (Croton tiglium L.) dan Pengembangan Teknologi Proses Ekstrak Terstandar Sebagai Bahan Laksatif. [skripsi]. Bogor: Sekolah Pascasarjana Institut Pertanian Bogor. 2008

9. Antonio S, Maria L ,F. Salatino, Giuseppina, N. Traditional Uses Chemistry and Pharmacology of Croton species (Euphorbiaceae). Jurnal Braz. Chem Soc. 2007; 18(1): 11-33.

10. Munir H, Shahid M, Subhani Z, Jabeen R. Activity-Guided Isolation of a Novel Protein From Foeniculum Vulgare With Antifungal and Antibacterial Activities. Matrix Sci Pharma. 2019;2(2):01-3. 
11. Iraqui $P$, Yadav RNS. Evaluation of Antibacterial and Antifungal Activities of Leaf and Seed Extracts of Croton tiglium Plant against Skin Disease Causing Microbes. Int J Res Stud Biosci [Internet]. 2015;3(5):139-44.

12. Youssef A, Aboulthana W, El-Feky A, Ibrahim N, Seif M, Hassan A. Evaluation of Antioxidant Efficiency of Croton tiglium L. Seeds Extracts after Incorporating Silver Nanoparticles. Egypt J Chem. 2019;62:181-200.

13. Dwiyanti RD, Widiningsih IK. Efektivitas Air Rebusan Daun Binahong (Anredera cordifolia) Terhadap Pertumbuhan Salmonella typhi. Medical Laboratory Technology Journal. 2015;1(1):1-6.

14. Setiati Siti, Alwi Idrus, dan Sudoyono Aru W et al [editor]. Buku Ajar Ilmu Penyakit Dalam Jilid I. Edisi VI. Jakarta: Interna Publishing. 2015.

15. Farmakologi dan terapi. Edisi V. Jakarta: Departemen Farmakologi dan Terapeutik Fakultas Kedokteran Indonesia, 2009.

16. Clinical Laboratory Standart Institute. Perfomance Standards For Antimicrobial Susceptibility Testing. $28^{\text {th }}$ ed. Wayne, PA;2018.

17. Backer CA, Bakhuizen van den Brink RC. Flora of Java. NVP Noordhoff, Groningen, The Nertherlands. 1963;1:477.

18. Cronquist A. An Integrated System of Classification of Flowering Plants. New York, USA: Columbia University Press.1981.16 p.

19. J.L.C.H van Valkenburg dan Bunyapraphatsara. PROSEA (Plants Resources of South-East Asia): Medicinal and poisonous plants.2002;12(2):202.

20. Saputera, Djumali Mangunwidjaja, dan Dyah Iswantini W et al [editor]. Mengenal Tanaman Kamandrah (Croton tiglium L.) Tanaman Multiguna. Cetakan 1. Bogor: Institut Pertanian Bogor.2015.

21. Mien DJ, Carolin WA, Firhani PA. Penetapan Kadar Saponin pada Ekstrak Daun Lidah Mertua (Sanseviera trifasciata prain varietas $S$. Laurentii)
Secara Gravimetri. Jurnal Ilmu dan Tekonologi Kesehatan. 2015;2(2):65-69.

22. Rompas RA, Edy HJ, Yudistira A. Isolasi dan Identifikasi Flavonoid dalam Daun Lamun (Syringodium Isoetifolium). Manado: Fakultas Matematika dan Ilmu Pengetahuan Alam Universitas Sam Ratulangi.2012;1(2):59-63.

23. Ngajow M, Abidjulu J, Kamu VS. Pengaruh Antibakteri Ekstrak Kulit Batang Matoa (Pometia pinnata) terhadap Bakteri Staphylococcus aureus secara in vitro.Jurnal MIPA UNSRAT Online.2013;2(2):132-182.

24. Darmawati AASK, Bawa IGAG, Suirta IW. Isolasi dan Identifikasi Senyawa Golongan Flavonoid pada Daun Nangka (Artocarpus heterophyllus Lmk) dan Aktivitas Antibakteri terhadap bakteri Staphylococcus aureus. Jurnal Kimia.2015;9(2):203-210.

25. Amalia S, Wahdaningsih S, Untari EK. Uji Aktivitas Antibakteri Fraksi n-Heksan Kulit Buah Naga Merah (Hylocereus polyrhizus Britton \& Rose) terhadap Bakteri Staphylococcus aureus ATCC 25923. Pontianak: Fakultas Kedokteran Universitas Tanjung Pura:Jurnal Fitofarmaka Indonesia.2016;1(2):61-64.

26. Nikham, Basjir TE. Uji Bahan Baku Antibakteri dan Buah Mahkota Dewa (Phaleria macrocarpa (scheff) Boerl). Hasil Radiasi Gamma dan Antibiotik terhadap Bakteri patogen. Serpong: Prosiding Pertemuan Ilmiah Ilmu Pengetahuan dan Tekonologi Bahan.2012

27. Hayati EK, Fasyah AG, Saadah L. Fraksinasi dan Identifikasi Senyawa Tanin pada Daun Belimbing Wuluh (Averrhoa bilimbi L.). Jurnal Kimia.2010;4(2):193200.

28. Wiyanto DB. Uji Aktivitas Antibakteri Ekstrak Rumput Laut Kappaphycus alvarezii dan Eucheuma denticullatum terhadap Bakteri Aeromonas hydrophila dan Vibrio harveyii. Jurnal Kelautan.2010;3(1):1-17.

29. Tamzil A, Sendry F, Aris DM. Pengaruh Jenis Pelarut Terhadap Persen Yield 
alkaloid dari Daun Salam India (Murraya koenigii. [Jurnal]. Palembang: Univeristas Sriwijaya.2014. Palembang:Jurusan Teknik Kimia, Fakultas Teknik,Univeristas Sriwijaya. Jurnal Teknik Kimia 2014;2(20).

30. Pradipta A. Pengaruh Metode Ekstraksi Terhadap Aktivitas Antibakteri Ekstrak Etanol Daun Sanseviera Trifasciata prain Terhadap Staphylococcus aureus IFO 13276 dan Pseudomonas aeruginosa IFO 12689 [Skripsi]. Yogyakarta: Universitas Atma Jaya Yogyakarta.2011

31. Soleha TU. Uji Kepekaan terhadap Antibiotik. Lampung: Bagian Mikrobiologi Fakultas Kedokteran Universitas Lampung.2015;5(9):119-123.

32. Syahdrajat T. Menulis Tugas Akhir Kedokteran dan Kesehatan. Jakarta: Prenadamedia Group.2015.

33. Ningsih DR, Zusfahair P. Potensi Ekstrak Daun Kamboja (Plumeria alba L.) Sebagai Antibakteri dan Identifikasi Golongan Senyawa Bioaktifnya. Jawa Tengah: MIPA FST Universitas Jenderal Soedirman Molekul.2014;9(2).105.

34. Fitri A, Wiranto A, Karina, Hawaidah N, Lestari E, Nurhidayati A, et al. Peralatan, Sterilisasi, dan Media Pertumbuhan Mikroba. Fakultas Kesehatan Masyarakat Universitas Mulawarman. Jurnal Praktikum Mikrobiologi Dasar .2014.

35. Dahlan M. Statistik untuk Kedokteran dan Kesehatan. $5^{\text {th }}$ ed. Jakarta : Salemba Medika; 2013.

36. Mukhriani. Ekstraksi, Pemisahan Senyawa, dan Identifikasi Senyawa Aktif. Junal Kesehatan. 2014;7(2):361-367.

37. Morgan, Michelle. Ethanol in Herbal Medicine. Mediherbal phytotheraphist's perspective. 2009;129:1-4.

38. Nuria CM, Faizatun A, Sumantri. Uji Aktivitas Antibakteri Ekstrak Etanol Daun Jarak Pagar (Jatropha Curcas L.) Terhadap Bakteri Staphylococcus aureus ATCC 25923, Escherchia coli ATCC 25922, dan Salmonella typhi ATCC 1408. Jurnal Ilmu Pertanian. Yogyakarta. 2009;2(9):26-37.
39. Clinical and laboratory standards institute. Perfomance standars for antimicrobial susceptibility testing; Twenty-fourth informational supplement. Usa: Pennsylvania. 2014; 34 (1): 75.

40. Lim SH, Darah I, Jain K. Antimicrobial Activities of Taninns Extracted from Rhizophora Apiculata Barks. Journal Of Tropical Forest Science. 2006;18(1):5965.

41. More S, Maldar NN, Bhamra $\mathrm{P}$, et al. Antimicrobial Activity of Naphtyl IsoQuinolone Alkaloids of Ancistrocladus heyneanus : I Extracted From Leaves. Pelagia Research Library. 2012;3(5):2760-2765.

42. Bhuiyan MNI, Chowdhury JU, Jarip B. Chemical components in volatile oil from Blumea balsamifera (L.). DC. J Bangladesh. 2009; 38(1); 107-110.

43. Hassan SM. Antimicrobial Activities of Saponin-Rich Guar Meal Extract. Texas. Poultry Science. 2008.

44. Hyldgaard M, Mygind T, Meyer RL. Essential Oils in Food Preservation: Modeofaction, Synergies, and Interactions with Food Matrix Components. Frontiers in Microbiology. 2012;3(12): 1-24.

45. Cardoso N, Cavalcante ATT, Araujo XA, and et al. Antimicrobial and Antibiofilm Action of Casbane Diterpene from Croton nepetaefoilus against oral bacteria. ELSEVIER. 2012: 550-555.

46. Kusumawati E, Supriningrum R, Rozadi R. Uji Aktivitas Antibakteri Ekstrak Etanol Daun Kecombrang Etlingera elatior (Jack) R.M.Sm Terhadap Salmonella typhi. Jurnal Ilmiah Manuntung. 2015;1(1): 1-7. 